\title{
АКТУАЛЬНЫЕ ВОПРОСЫ ОБЩЕСТВЕННОГО КОНТРОЛЯ В СИСТЕМЕ ЗАКУПОК ТОВАРОВ, РАБОТ, УСЛУГ ДЛЯ ГОСУДАРСТВЕННЫХ И МУНИЦИПАЛЬНЫХ НУЖД
}

\author{
(c) 2021 Казанкова Татьяна Николаевна \\ кандидат педагогических наук, доцент кафедры публичного права \\ Самарский государственный экономический университет, Россия, Самара \\ E-mail: tatianaok78@yandex.ru \\ (c) 2021 Новикова Кристина Дмитриевна \\ ведущий инженер \\ Департамент управления делами Губернатора Самарской области \\ и Правительства Самарской области, Россия, Самара \\ E-mail: kristinnovik163@yandex.ru
}

В данной статье раскрыты вопросы общественного контроля в системе закупок товаров для государственных и муниципальных нужд. Раскрыты вопросы проведения открытого и закрытого конкурса, а также электронного аукциона. Раскрываются электронные торговые площадки, на которых проводятся электронные торги, а также то, что каждый желающий может проверить правильность их проведения.

Ключевые слова: открытый и закрытый конкурс, Единая информационная система, заказчик, победитель, электронный аукцион.

На сегодняшний день для удовлетворения государственных и муниципальных нужд проводятся государственные закупки. В последние несколько лет данному вопросу уделяют повышенное внимание. Для отечественных предприятий в этом году государство увеличивает количество заказов, это произошло на фоне карантина, финансового кризиса и введенных санкций. Государство страны делает это для того, чтобы поддержать и оживить отечественную экономику, так как большое количество предприятий были вынуждены сократить объемы производства, количество работников и другое. Перед отечественными предприятиями стоит задача экономно расходовать бюджетные средства, и при этом получать максимальную выгоду [1].

Лучше всего будет проведение государственных закупок в открытой форме, в таком случае заказчик должен составить требования к потенциальным участникам согласно части 1 статьи 4844 Федерального Закона, также он разрабатывает документацию, которую участники должны заполнить и предоставить на конкурс. После того как заказчик все разработал и составил, он размещает всю информацию в ЕИС. В этом случае все заинтересованные лица получают доступ одновременно. Компании, которые желают участвовать в данном конкурсе, должны предоставить свои предложения, как они планируют исполнять государственный контракт. Заказчик каждую заявку проверяет на соответствие предъявленным требованиям, составляет рейтинг. В нем первые места занимают те компании, которые максимально достоверно выполнили все требования, которые предъявлял заказчик. Та организация, которая заняла в данном рейтинге первое место, считается победителем в данном конкурсе.

Способы декларирования и предложения государственных контрактов определяются законом. Они включают в себя [2]:

- Заявки на участие в аукционе

- Аукционы, в том числе электронные;

- Запрос предложений;

- Предложение контракта одному подрядчику;

- Размещение заказов на товарных биржах, если цена контракта превышает сумму в 5 миллионов рублей (примерно 170000 долларов США).

Для достижения экономии бюджетных средств заказы, размещенные на аналогичные товары или услуги одним и тем же государственным заказчиком, должны выполняться 
одновременно. Заявки на участие в тендерах и аукционах должны быть открыты большую часть времени. Закрытые торги допускаются, когда договором предусмотрена поставка товаров или выполнение работ или оказание услуг, сведения о которых засекречены.

Разница между конкурсом заявок и аукционом заключается в том, что при объявлении тендера контракт присуждается подрядчику, который предлагает наилучшие условия для выполнения контракта. На аукционах контракт присуждается анонимному подрядчику, который предлагает самую низкую цену за контракт. С 1 января 2010 года квалификация подрядчика считается важным фактором при заключении контракта, в дополнение к требованию о том, чтобы контракт был присужден участнику торгов по самой низкой цене. При выполнении строительных работ были установлены особые требования к квалификации подрядчика. Для участия в аукционе подрядчик должен иметь не менее пяти лет опыта выполнения аналогичных работ и доказать, что в своих предыдущих проектах он выполнил не менее 30\% контрактных работ на конкретной строительной площадке [3].

Заявки объявляются на сайте агентства, которое намерено предложить контракт, и победителем становится подрядчик, предложивший самую низкую цену. Данный вид рекламы имеет ограничения, обусловленные сроком действия контракта и его суммой (не более 10000 долларов США в квартал), и обычно используется для оказания услуг государственным организациям, расположенным в зарубежных странах.

Контракт может быть предложен одному подрядчику, если:

- Соглашение относится к деятельности субъектов естественных монополий;

- Государство приобретает культурные ценности;

- Исполнитель обладает исключительными правами на предложение запрашиваемых товаров, работ или услуг;

- Контракт предусматривает выполнение работ, связанных с военно-мобилизационной деятельностью.

В некоторых случаях государственный контракт может быть заключен без конкурса. Обход предписанных правил допускается в тех случаях, когда трудоемкие процедуры были бы контрпродуктивны в случае форс-мажорных обстоятельств и необходимости срочного медицинско- го вмешательства.

В ноябре 2009 года в Российской Федерации был утвержден перечень товаров, услуг и работ, которые с 1 января 2010 года должны закупаться федеральными заказчиками только на открытых интернет-аукционах. В настоящее время в этот перечень входят строительные контракты, контракты, связанные с поставкой медикаментов, продуктов питания, оргтехники. С 1 июля 2010 года все традиционные аукционы будут запрещены, а все аукционы будут проводиться исключительно онлайн. Для провинциальных и муниципальных заказчиков это требование вступит в силу с 1 января 2011 года. Ожидается, что до 70\% всех государственных контрактов будут распределяться через интернет-аукционы. Остальные 30\% контрактов (в первую очередь на научноисследовательские, инженерные, архитектурноконструкторские и медицинские услуги) будут заключаться на конкурсной основе [4].

Первоначально закон требовал, чтобы объявления о государственных контрактах публиковались на веб-сайте организации-заказчика и в официальном издании, которое является специальной газетой, назначенной федеральным Министерством экономического развития. Объявления должны быть опубликованы не позднее чем за 30 дней до вскрытия запечатанных конвертов с предложениями/запросами. Правительству пришлось синхронизировать газетную и интернет - публикацию объявления о контракте. С 1 января 2008 года отменено требование публиковать информацию о государственных контрактах в федеральных средствах массовой информации, а с 1 января 2010 года единственным официальным источником информации по всем государственным контрактам является Федеральный интернет-портал, находящийся в ведении Министерства экономического развития Российской Федерации. На этом портале публикуется информация обо всех контрактах, предлагаемых федеральными, провинциальными и муниципальными властями. Публикация информации о государственных закупках в средствах массовой информации субъектов Российской Федерации прекращается с 1 января 2011 года. Ожидается, что это упростит правовой контроль для обеспечения того, чтобы все контракты заключались в соответствии с требованиями законодательства, повысит прозрачность и исключит возможность дальнейшего исправления контрактной информации, а 
также расширит возможности для подрядчиков, которые больше не будут обязаны проверять несколько источников информации [5].

Информация на этом правительственном сайте должна быть опубликована на русском языке, без рекламы и доступна любому лицу в любое время, бесплатно и без каких-либо ограничений. От этой публикации освобождаются только те договоры, которые содержат сведения, составляющие государственную тайну. Для доступа к этой информации не требуется специального оборудования, компьютерных программ или навыков. По соображениям безопасности требуется использование электронных подписей, Электронная регистрация сделок и ежедневное резервное копирование информации.

Согласно российскому законодательству, все цены по государственным контрактам фиксируются и определяются в договоре при его заключении. Корректировка цены контракта допускается, если:

- Естественные монополии должны компенсировать инфляцию;

- Государственный орган настаивает на изменении договора в целях увеличения объема выполняемых работ и оказываемых услуг;

- Долгосрочный контракт стоимостью более 10 млрд. руб. (300 млн. долл. США) не может быть исполнен без изменения цены из-за значительного увеличения стоимости контракта.

Авансовые платежи не могут превышать 30\% от цены контракта, и подрядчик должен доказать, что он обеспечил средства для выполнения своих договорных обязательств в размере, равном 1/3 от цены контракта. Нет никакого требования к подрядчику покупать страховку от нарушения контракта [6].

Бюджетный кодекс Российской Федерации предусматривает трехлетний бюджетный цикл.
Это позволяет агентствам заключать государственные контракты сроком на три года. Контракты на реализацию долгосрочных федеральных государственных целевых программ могут заключаться на срок действия этих программ и не ограничиваются тремя годами.

Подрядчик, подавший заявку на участие в аукционе, не может отказаться от акцепта контракта, если впоследствии ему будет предоставлен контракт. Если подрядчик не может выполнить подрядные работы в полном объеме, часть контракта может быть присуждена подрядчику, который был оценен следующим в очереди.

Особое внимание уделяется организациям, представляющим или принимающим на работу инвалидов, а также исправительным учреждениям. Эти организации могут потребовать повышения цены контракта до 15\%.

Закон предусматривает, что не менее $15 \%$ всех государственных контрактов должны заключаться с малым бизнесом.

Таким образом, закон не предусматривает ограничений на гражданство исполнителя. Хотя закон устанавливает национальный режим государственных закупок, иностранные подрядчики и поставщики участвуют в тендерах и аукционах и имеют те же права, что и российские юридические лица. Однако правительство может вводить запреты или ограничения на закупку товаров, работ и услуг, произведенных за пределами России, в случае заключения военных контрактов или когда речь идет о национальной безопасности.

Исчерпывающей информации о доле государственных контрактов, заключенных с иностранными компаниями, нет. Однако доля иностранных компаний, заключающих контракты для российского правительства, может быть оценена путем сравнения [7].

\section{Библиографический список}

1. Агешкина Наталья Александровна Конкурентное право. Учебное пособие / Агешкина Наталья Александровна.-М.: Дашков и $\mathrm{K}^{\circ}, 2018 .-951$ с.

2. Казанкова Т. Н. Проблемы. и перспе.ктивы финансового контроля в России / Т. Н. Казанкова, А. С. Федотчева // Российская наука: Актуальные исследования и разработки: Сборник научных статей III. Всероссийской заочной научно.практической конференции: В 2.-х ч.- Самарский государственный экономический университет, 2017.-С. 358-361.

3. Казанкова Т.Н. Проблемы взаимодействия гражданского общества. и государства // Вестник Самарского муниципального института управления. - 2.014. - № 3. С. 7/5-81.

4. Минто Золотые правила Гарварда. и McKinsey. Правила маги.ческой пирамиды для дело.вого письма: моногр. / Минто, Барбара.- М.: Росмэн, 2018. - 192 с. 
5. Попондопуло, В.Ф. Конкурентное право. Учебник и практикум для бакалавриата и магистратуры / В. Ф. Попондопуло.-М.: Юрайт, 2018.- 567 с.

6. Самолысов, П. В. Конкурентное право: глоссарий понятий / П. В. Самолысов.- М.: Норма, 2018. - 810 с.

7. Цинделиани, И. А.Антимонопольное (конкурентное) право // И.А.Цинделиани.- Москва/: Машиностроение, 2018. - 906 с. 